\title{
Trombocitaaggregáció-gátlás akut koronária szindrómán átesett betegek magas kockázatú alcsoportjaiban
}

\author{
Kezelési ajánlás a Magyar Kardiológusok Társaságának Thrombosis Munkacsoportjától \\ a hazai finanszírozási protokoll figyelembevételével
}

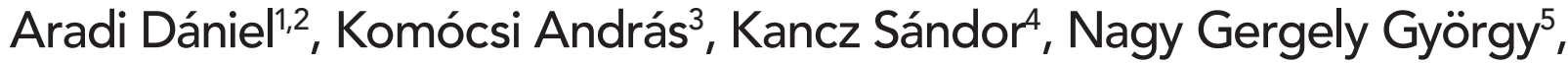 Kiss Róbert Gábor ${ }^{6}$, Merkely Béla²}

\author{
1'Állami Szívkórház, Aktív Kardiológia Osztály, Balatonfüred \\ ${ }^{2}$ Semmelweis Egyetem, Városmajori Szív- és Érgyógyászati Klinika, Budapest \\ ${ }^{3}$ Pécsi Tudományegyetem, Szívgyógyászati Klinika, Pécs \\ ${ }^{4}$ Gottsegen György Országos Kardiológiai Intézet, Felnőtt Kardiológiai Osztály, Budapest \\ ${ }^{5}$ Borsod-Abaúj-Zemplén Megyei Központi Kórház és Egyetemi Oktatókórház, I. sz. Belgyógyászat - Kardiológiai \\ Osztály, Miskolc \\ ${ }^{6}$ Magyar Honvédség, Állami Egészségügyi Központ, Kardiológiai Osztály, Budapest
}

Levelezési cím:

Dr. Aradi Dániel, e-mail: daniel_aradi@yahoo.com

\begin{abstract}
Akut koronária szindrómán (ACS) átesett betegek körében a recidív iszkémiás események kivédésére alapvető fontosságú a kettős trombocitaaggregáció-gátlás, amely során az aszpirin mellé jellemzően egy évig egy ADP-receptor-gátló kombinációja javasolt. Az elérhető ADP-receptor-gátlók közül az Európai Kardiológus Társaság aktuális szakmai irányelvei ACS-en átesett betegeknél rutinszerủen a hatékonyabb aggregációgátlást létrehozó prasugrel vagy ticagrelor alkalmazását preferálják, clopidogrel csak akkor javasolt, ha az elöbbiekkel szemben kontraindikáció áll fenn, vagy a hatékony szerek nem elérhetők. Hazánkban a prasugrel és ticagrelor rutinszerű alkalmazását a gyógyszerár-támogatási protokollok szűkebb, magasabb kockázatú csoportokra szabják, de a támogatási szabályozás az elmúlt években kedvezően változott, jelentős előrelépést hozva magas kockázatú betegek optimális aggregációgátló kezelésében. Ugyanakkor a finanszírozás szabta lehetőségek és az ESC szakmai útmutatók között feszülö részleges ellentétekben sokszor nem egyértelmü, hogy a kiemelt alcsoportokban milyen szakmai szempontok támasztják alá a javasolt aggregációgátló választást. Ezért a Magyar Kardiológusok Társaságának Thrombosis Munkacsoportja az a célt tűzte ki, hogy egy szakértői javaslat keretén belül összefoglalja az egyes magas kockázatú ACS-alcsoportokban elérhető aktuális, releváns tudományos eredményeket és ezekből a napi klinikai rutin számára hasznosítható, gyakorlati javaslatokat fogalmaz meg az optimális aggregációgátló kezelésröl.
\end{abstract}

Kulcsszavak: trombocitaaggregáció-gátlás, magas kardiovaszkuláris kockázat, clopidogrel, prasugrel, ticagrelor

Antiplatelet treatment of high-risk patients following acute coronary syndromes: treatment guidance of the Working Group on Thrombosis of the Hungarian Society of Cardiology implementing national reimbursement protocols Dual antiplatelet treatment, which generally involves the administration of acetyl-salicylic acid combined with an ADP-receptor blocker for one year, plays a fundamental role in preventing recurrent ischemic events among patients after acute coronary syndromes (ACS). Current treatment guidelines of the European Society of Cardiology (ESC) prefer the routine administration of the more potent antiplatelet agent prasugrel or ticagrelor from the available ADP-receptor blockers for patients after an acute coronary event. Clopidogrel is recommended only, if the more effective drugs are contraindicated or not available. However, routine use of prasugrel or ticagrelor in Hungary have been restricted by reimbursement protocols for certain high-risk patient populations. The reimbursement regulations were favourably amended in recent years, which was a major step forward in the optimal antiplatelet treatment of these high-risk patients. However, the contradictions between the national financial protocols and the ESC professional guidelines often make it unclear which evidence the recommended antiplatelet therapy is based on in high-risk patient subgroups. To address this uncertainty, the Working Group on Thrombosis of the Hungarian Society of Cardiology prepared this consensus recommendation to review the relevant scientific evidence behind the antiplatelet treatment of selected high-risk populations of ACS and to provide guidance for routine clinical practice.

Keywords: antiplatelet therapy, high cardiovascular risk, clopidogrel, prasugrel, ticagrelor 


\section{Bevezetés}

A vérlemezke-aktiváció és aggregáció folyamata alapvetően fontos az aterotrombotikus folyamatok létrejöttében: a plakkruptúra vagy erózió révén aktivált vérlemezkék kitapadnak a subendothelialis területből szabaddá váló ligandmolekulákhoz, aktiválódnak, aggregálódnak, és a párhuzamosan beinduló koagulációs kaszkád fontos lépéseit kifordult felszínükön katalizálva létrehozzák a verőérthrombust (1). Nem véletlen, hogy a bekövetkezett trombotikus események kezelésében, és az ismételt események megelőzésében nagy jelentőségű a kombinált vérlemezkegátlás (2). Jelen ismereteink szerint a vérlemezkegátlás két fő blokkolandó útvonala közül az egyik a tromboxán-szintézist érinti, hiszen az aszpirin a ciklooxigenáz-1 enzim irreverzibilis bénítása révén gátolja a tromboxán-képződést (3). A hatékony vérlemezkegátláshoz akut koronária szindróma (ACS) esetén szükséges az ADP-mediálta aggregáció fékezése is, amelyet a $\mathrm{P} 2 \mathrm{Y}_{12}$-receptort blokkoló

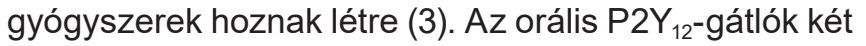
fő családba sorolhatók: az irreverzibilis ADP-receptorgátlást előidéző thienopyridinek és a reverzibilis receptorkötést létrehozó ticagrelor. A thienopyridinek közé tartozó clopidogrel hatása közepes erősségű, lassan kialakuló, jelentős egyének közötti variabilitással bír. Ehhez képest a másik thienopyridin, a prasugrel gyorsabb, erélyesebb és egységesebb aggregációgátlást eredményez, elsősorban hatékonyabb aktív metabolitképződése révén (mindketten prodrugok) (3). A ticagrelor nem prodrug, maga az aktív molekula felszívódva egyből képes a $\mathrm{P} 2 \mathrm{Y}_{12}$-receptor bénítására, de a plazmakoncentráció-csökkenés hatására a receptorról képes leválni, és normál funkciójú vérlemezkéket hagy maga után. Hasonlóan a prasugrelhez a ticagrelor is erélyes, gyors, hatékony $\mathrm{P}_{2} \mathrm{Y}_{12}$-gátlást eredményez (3). ACS esetén különösen lényeges a hatékony aggregációgátlás: a klinikai tanulmányok egyértelműen igazolták a hatékonyabb és egységesebb $\mathrm{P}_{2 Y_{12}}$-receptorgátlók előnyeit az iszkémiás végpontok csökkentésében a clopidogrelhez képest $(4,5)$. Emiatt az Európai Kardiológus Társaság (ESC) irányelvei ACS miatt kezelt betegeknél a prasugrel vagy ticagrelor alkalmazását preferálják clopidogrelhez képest; clopidogrel csak akkor javasolt, ha kontraindikáció áll fenn vagy a hatékonyabb szerek nem elérhetők $(2,6)$. Ezzel a szakmai javaslattal szemben a hazai gyógyszer-finanszírozási protokoll csak válogatott esetekben támogatja a prasugrel vagy ticagrelor alkalmazását, amely rendelet az elmúlt években többször módosításra került. Míg 2011-ben a rendeletben clopidogrel allergia vagy laboratóriumilag igazolt clopidogrel nonreszponzió volt szükséges a prasugrel $70 \%$-os támogatással (Eü70 24) történő rendeléséhez ACS miatt PCl-n átesett betegeknél, addig 2015-ben a módosított rendelet alapján a clopidogrel allergiás vagy nonreszponder betegek mellett a diabéteszes és stenttrombózison átesett betegek is felkerül- tek a prasugrel mellett támogatható kategóriák közé. Legutóbb 2018 októberében jelent meg az ismételten módosított támogatási szabályozás, amelyben a korábbi Eü70 24-es pontban a prasugrel mellett már a ticagrelor támogatott rendelését is lehetővé tették. Emellett a ticagrelor számára egy új, Eü70 30-as támogatási pontot is hirdettek olyan ACS-en átesett betegeknél, akik krónikus veseelégtelenségben szenvednek $(\mathrm{CrCl}<60$ $\mathrm{ml} / \mathrm{min}$ ). Bár mindezek, a finanszírozó által kiemelt magas kockázatú csoportok még továbbra sem teljesítik teljességgel az ESC szakmai irányelveit, lényeges bővítés és nyitás érhető tetten a korábbi évekhez képest. Ezen lehetőségek ellenére a Magyar Infarktus Regiszter adatai alapján nem változott lényegesen az új, hatékony ADP-receptor-gátlók térnyerése a hazai napi gyakorlatban: egy 2010-2016 közötti 57214 beteg adatait feldolgozó elemzés szerint ST-elevációs infarktusban 4,2\%-os, míg nem ST-elevációs infarktusban 2,4\%-os volt a prasugrel alkalmazás aránya, ticagrelor nem volt kimutatható (7). Egy 2015-ös elemzés szerint a prasugrel alkalmazása országos szinten továbbra is indokolhatatlanul alacsony szinten állt, a betegek 8,1\%-ban kapták a kórházi kezelés során (8). Mindezek az eredmények felvetik annak a lehetőségét, hogy az elmúlt évtized restriktív szabályozása „kiölte” ezen terület guideline-szemléletü kezelését és még messze a restriktív szabályozás korlátjait sem használjuk ki a napi gyakorlatunkban. Mivel ezek a hiányosságok döntően hozzájárulhatnak a régiós átlaghoz képest rosszabb 1 éves infarktustúléléshez (9), a Magyar Kardiológusok Társaságának Thrombosis Munkacsoportja úgy döntött, hogy megkísérli összefoglalni azokat az elérhető tudományos szakmai bizonyítékokat, amelyek a magyar finanszírozási szabályok által kiemelt magas kockázatú betegcsoportok ACS utáni optimális aggregáció-gátló kezelését, kiemelten a $\mathrm{P}_{2} \mathrm{Y}_{12}$-gátló választást meghatározzák. Ezek alapján a következőkben részletesen elemzett magas kockázatú alcsoportok a következők: - diabetes mellitus,

- krónikus veseelégtelenség,

- clopidogrel nonreszponzió,

- stenttrombózis utáni állapot,

- stroke utáni állapot.

\section{Diabéteszes betegek}

Konszenzusjavaslatok, fóbb megállapítások

1. A diabétesz jelentősen fokozza akut koronária szindróma után a visszatérő trombotikus szövődmények kockázatát és növeli az összmortalitást. Ezen kedvezőtlen hatásokban döntő szerepet játszik a kiterjedt, akcelerált ateroszklerózis mellett fennálló fokozott vérlemezke-aktivitás és a csökkent vérlemezkegátló hatékonyság.

2. A diabétesszel bíró betegeknél a prasugrel és ticagrelor alkalmazása jelentősen csökkenti a kardiovaszkuláris halál, miokardiális infarktus és stroke- 
kockázatát, míg a vérzéses kockázat a hatékonyabb aggregációgátlás ellenére jelentősen nem fokozódik. Emiatt ebben a betegcsoportban kontraindikáció hiányában minden betegnél a prasugrel vagy ticagrelor preferált clopidogrellel szemben.

\section{Vizsgálati háttér}

Ismert, hogy a diabétesz (DM) megléte hasonló mértékben rontja a kardiovaszkuláris kimenetelt, mint egy korábban átvészelt szívinfarktus (10). Ezt a régebben felismert összefüggést támasztja alá két friss publikáció is: a THEMIS-vizsgálatban még szív- és érrendszeri eseményt el nem szenvedett DM-betegeknél az aszpirin monoterápia mellett hasonló és lineárisan növekvő kardiovaszkuláris kockázat látszott, mint hasonló terápia mellett a PEGASUS-vizsgálat szívinfarktuson átesett betegeinél (11-13). A rosszabb klinikai kimenetelért a diabéteszre jellemző diffúz, a kiáramlási pályát is érintő, legtöbbször többágrendszeri, meszes szűkületek formájában megjelenő malignus ateroszklerózis, a fokozott vérlemezke-aktivitás, az akcelerált gyulladás és protrombotikus alvadási státusz egyaránt felelős. Az inzulinra szoruló diabéteszes betegekre mindez hatványozottan igaz, és a kockázat a DM fennállásának idejével összhangban fokozódik. Ismert, hogy számos mechanizmus révén a DM-betegeknél fokozódik a vérlemezke-aktiváció és -aggregáció, gyorsul a napi vérlemezke-körforgás (14). Angiolillo és munkacsoportja több lényeges tanulmányban bemutatta, hogy a DM-betegeknél a clopidogrel hatékonysága jelentősen csökkent a non-DM-betegekhez képest $(15,16)$. A fokozott vérlemezke-aktiváció mellett ennek hátterében részben a clopidogrel sokkal rosszabb hepatikus átalakulása igazolódott, ugyanis a cukorbetegekben kevesebb aktív metabolit képződik. Ezen hatások révén a clopidogrelkezelt DM-betegekben jelentősen fokozódik a magas trombocitareaktivitás (HPR) aránya, amely a trombotikus szövődmények ismert rizikófaktora. A clopidogrelhez képest DM esetén mind a prasugrel, mind a ticagrelor fokozza a vérlemezkeaggregáció-gátlás hatékonyságát és egységességét, csökkentik a magas trombocitareaktivitás előfordulását. Ezen farmakodinámiás előnyöket egyértelmüen visszatükrözik a nagy esetszámú randomizált klinikai tanulmányok.

A prasugrel hatékonyágát és biztonságosságát $A C S$ miatt PCI-n átesett DM-betegeknél a TRITON TIMI38 randomizált vizsgálatban elemezték a clopidogrelhez képest (4). A 13608 betegből 3146-nál (23\%) szerepelt az anamnézisben diabétesz, negyedük inzulinkezelést is kapott. A diabétesz jelenléte a vizsgálatban jelentősen fokozta a kardiovaszkuláris halálozás, infarktus és stenttrombózis előfordulását $(p<0,001)$, erős trend $(p=0,08)$ volt a major vérzéses kockázat emelkedésére is diabétesz esetén. A diabéteszes alcsoportban a prasugrel a clopidogrelhez képest szignifikáns, jelentős előnyt hozott a kardiovaszkuláris halál, miokardiális infarktus és stroke vonatkozásában (HR: 0,70; 95\% Cl:
A

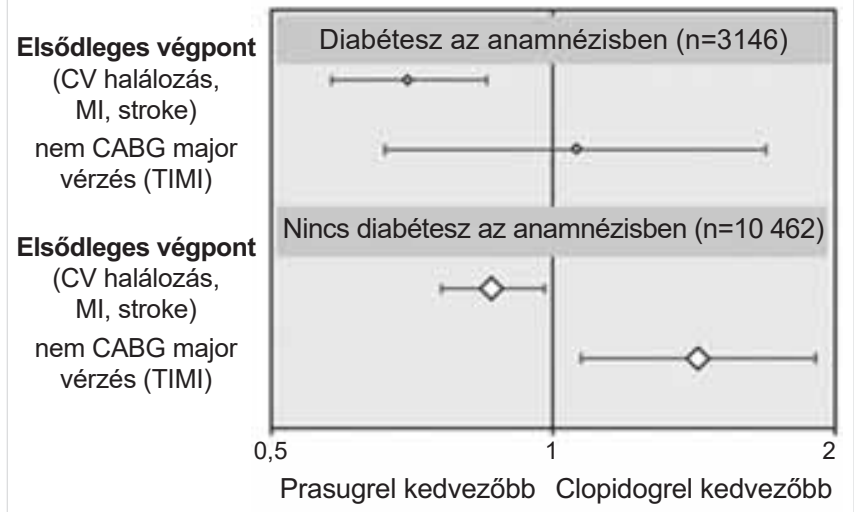

B

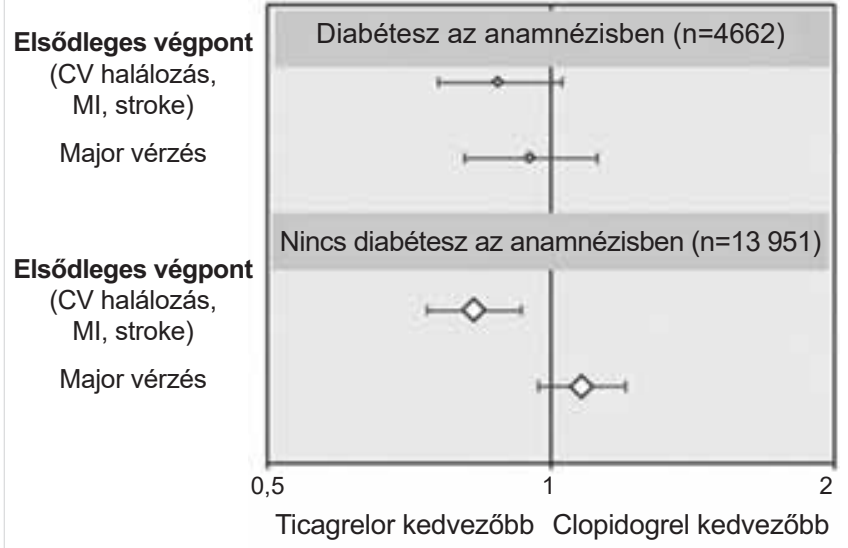

1. ÁBRA. A diabétesz jelentősége a trombotikus és vérzéses szövődmények rizikójára ACS-en átesett betegeknél.

Az ábra A-jelū része a prasugrel hatékonyságát és biztonságosságát mutatja a clopidogrelhez képest, míg a B-jelü rész a ticagrelort veti össze a clopidogrellel (CV: kardiovaszkuláris, Ml: miokardiális infarktus)

0,58-0,85 p<0,001) (1. ábra), amely $30 \%$-os relatív rizikócsökkenés a nem diabéteszes beteghez képest (14\%) 2-szeres relatív előnyt mutatott. Az inzulinnal kezelt diabéteszes betegeknél ez a relatív rizikócsökkenés még jelentősebb volt (inzulin: $37 \%$ vs. $26 \%$ nem-inzulin). Ugyanakkor a diabéteszes alcsoportban a major vérzéses szövődmények előfordulása nem fokozódott a clopidogrelhez képest (HR: 1,06; 95\% Cl: 0,66-1,69 $\mathrm{p}=0,81)$ (1. ábra).

A PLATO-vizsgálatban ACS miatt bármely módon kezelt betegeken hasonlították össze a ticagrelor és a clopidogrel hatékonyságát a diabétesz jelenléte és a $\mathrm{HBA}_{1 \mathrm{c}}$-értékek függvényében $(5,17)$. Az anamnézis alapján diabéteszes betegeknél hasonlóan hatékony volt a ticagrelor a clopidogrelhez képest, mint a nem diabéteszes betegeknél, a relatív rizikócsökkenés mértéke a diabéteszes és nem diabéteszes csoportban konzisztens volt (1. ábra). Ugyanakkor abban az esetben, ha a betegcsoportot a bevonási $\mathrm{HBA}_{1 \mathrm{c}}$ alapján felosztották $6 \%$ alatti és feletti alcsoportra, a ticagrelor a $6 \%$ feletti alcsoportban (diabétesz+prediabétesz) lényegesen nagyobb előnyt demonstrált a kardiovaszkuláris halál, infarktus, stroke 
összetett végpontjában (HR: 0,80; 95\% Cl: 0,70-0,91), mint a $6 \%$ alatti betegek (HR: 0,93; 95\% Cl: 0,79-1,09). $A$ vérzéses végpont tekintetében a diabétesz jelenléte nem befolyásolta a ticagrelor biztonságosságát, nem volt szignifikáns különbség az elsődleges biztonságossági végpontban a ticagrelor és clopidogrel között (HR: 0,95; 95\% Cl: 0,81-1,12) (1. ábra).

Bár nem ACS-en átesett betegpopulációt vizsgált, a ticagrelor hatékonyságáról és biztonságosságáról diabéteszben új információkat hozott a THEMIS randomizált vizsgálat (11). A vizsgálatba igazolt koronáriabetegséggel bíró $\mathrm{PCl}-\mathrm{n}$, illetve CABG-n átesett vagy jelentős reziduális koronáriaszűkülettel bíró 50 év feletti diabéteszes betegeket vontak be, akiknél korábbi kardiovaszkuláris esemény nem volt. Az aszpirin monoterápiához képest az aszpirin plusz 2×60 mg-os ticagrelor stratégia jelentősen csökkentette a kardiovaszkuláris halál, infarktus vagy stroke végpontját (HR: 0,90; 95\% Cl: 0,81-0,99), különösen, ha a beteg a $\mathrm{PCl}-n$ átesett csoportba tartozott. Ezek az eredmények erősítik a ticagrelor alkalmazásának esetleges előnyeit a diabéteszesek között, bár a stabil koronáriabetegeknél a vérzéses kockázat pontos felmérése szükséges, mert a hatékonyabb aggregációgátlás növelte a vérzéses események előfordulását (TIMI major és minor vérzés: HR: 2,49; 95\% Cl: 2,02-3,07 p<0,001).

\section{Krónikus veseelégtelenséggel bíró betegek}

Konszenzusjavaslatok, fóbb megállapítások 1. A krónikus veseelégtelenség mind a vérzéses kockázat, mind az iszkémiás rizikó jelentős növekedésével jár, amelynek hátterében a koagulációs rendszer, a vérlemezke-aktiváció összetett, gyakran ellentétes változásai és a gyógyszerhatóanyagok farmakokinetikájának változásai állnak, amelyek az optimális antitrombotikus terápia megválasztását jelentősen nehezítik. Ez az egyik alapja annak, hogy a veseelégtelen betegeknél az evidenciaalapú gyógyszeres kezelés aránya lényegesen rosszabb, mint a normál vesefunkciójú betegeknél.

2. Krónikus veseelégtelen $(\mathrm{CrCl}<60 \mathrm{ml} / \mathrm{min})$, akut koronária szindrómán átesett betegeknél ticagrelor kezelés preferált clopidogrellel szemben egy évig, mert ebben a betegcsoportban a ticagrelor terápia abszolút előnye az iszkémiás események megelőzésében lényegesen nagyobb, mint a nem veseelégtelen betegeknél, míg a vérzéses rizikó nem fokozódik. A prasugrel hatékonysága és biztonságossága nem változik a veseelégtelenség függvényében.

\section{Vizsgálati háttér}

A krónikus veseelégtelenség jelentősen fokozza a szívés érrendszeri betegségek kockázatát a hagyományos rizikófaktorok jelenlététől függetlenül (18). A vesefunkció romlása egyértelműen jelzi a párhuzamosan emelkedő kardiovaszkuláris halálozás rizikóját, de az albuminu- ria romlása a GFR-értéktől függetlenül is kardiovaszkuláris rizikófaktornak tekintendő. Mindezek alapján az ESC prevenciós ajánlása a súlyos veseelégtelenségben szenvedő betegeket (GFR $<30 \mathrm{ml} / \mathrm{min} / 1,73 \mathrm{~m}^{2}$ ) az igen magas kockázatú, míg a középsúlyos veseelégtelen betegeket (GFR: $30-59 \mathrm{ml} / \mathrm{min} / 1,73 \mathrm{~m}^{2}$ ) a magas kockázatú csoportba sorolja (19). Akut koronária szindrómás betegek teljes spektrumában már az enyhe vagy középsúlyos veseelégtelenség is jelentősen fokozza a miokardiális infarktus vagy a halálozás gyakoriságát. A fokozott eseménygyakoriság mechanizmusa nem teljesen tisztázott, az akcelerált érelmeszesedés, az oxidatív stressz, gyulladásos folyamatok, valamint a fokozott trombocitareaktivitás mind szerepet játszhat benne. Az iszkémiás események magasabb rizikója mellett ismert a veseelégtelen betegek magasabb a vérzéses kockázata is (20). Ebben az összetett, egyaránt fokozott vérzéses és iszkémiás rizikóval bíró állapotban gyakran egymást erősítő, máskor egymással ellentétes hatások kerülnek érvényre, amelyek a koagulációs kaszkád és a vérlemezke-aktiváció különböző pontjait érintik. Ez lehet az egyik oka annak, hogy a magas vérzéses és iszkémiás rizikótól tartva a normál vesefunkciójú betegekhez képest a krónikus veseelégtelen egyének lényegesen kisebb arányban részesülnek evidenciaalapú kezelésben. A PLATO-vizsgálat a ticagrelor hatékonyságát és biztonságosságát hasonlította össze a clopidogrellel szemben 18624 akut koronária szindróma miatt kezelt betegnél (5). A randomizációkor 15202 beteg esetében volt ismert a vesefunkció, 3237 (21\%) esetben krónikus veseelégtelenség (GFR $<60 \mathrm{ml} /$ perc) állt fenn. A ticagrelor a clopidogrelhez képest szignifikáns mértékben (HR: 0,77; 95\% Cl: 0,65-0,90) (2. ábra) csökkentette a primer iszkémiás végpont gyakoriságát, úgy, hogy az abszolút rizikócsökkenés lényegesen nagyobb mértékü volt, mint a normális vesefunkciójú betegek között $(4,1 \%$ vs. 1,0\%). A krónikus vesebeteg-csoportban a ticagrelor szignifikánsan csökkentette az összhalálozást is. A fenti kedvező eredmények úgy születtek meg, hogy a két csoport között nem volt szignifikáns különbség a major vérzéseket, a fatális vérzéseket, valamint a non-CABG vérzéseket illetően (2. ábra) (21). A fenti eredményeket támogatja az az alcsoport-elemzés is, amelyben a veseelégtelenséggel gyakran társuló, a kockázatot tovább fokozó klinikai tényező, a diabétesz hatását vizsgálták (17). A PLATO-vizsgálatba bevont akut koronária szindrómás betegeket a diabétesz és krónikus veseelégtelenség jelenléte alapján alcsoportokra osztották. Egyértelmü volt, hogy bármelyik alcsoportot is vizsgálták a ticagrelor kedvező hatása a clopidogrellel szemben megmarad, de a legnagyobb mértékủ abszolút rizikócsökkenés a primer összetett kardiovaszkuláris végpontot illetően a diabéteszes vesebetegek csoportjában nyilvánult meg. Különösen fontos tény az is, hogy ugyan mind a diabetes mellitus mind a krónikus vesebetegeség a vérzésveszélyt is számottevően megemeli, a diabéteszes vesebetegek csoportjában nem 
A

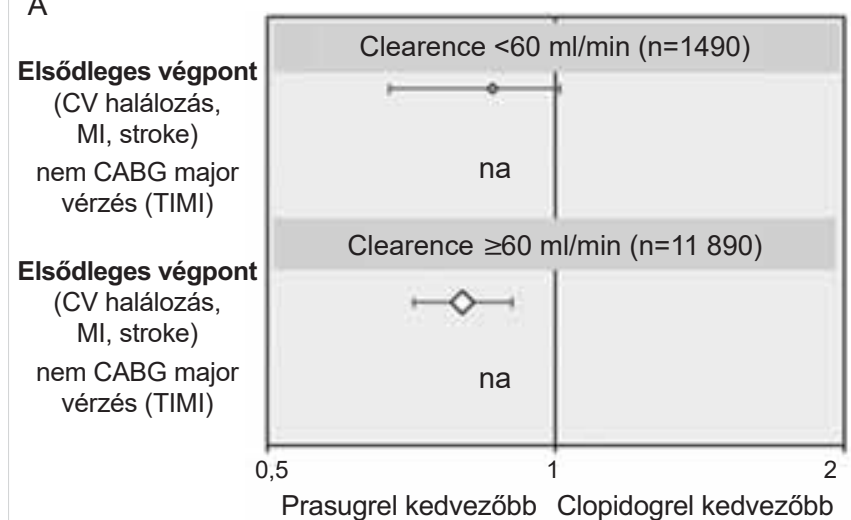

B

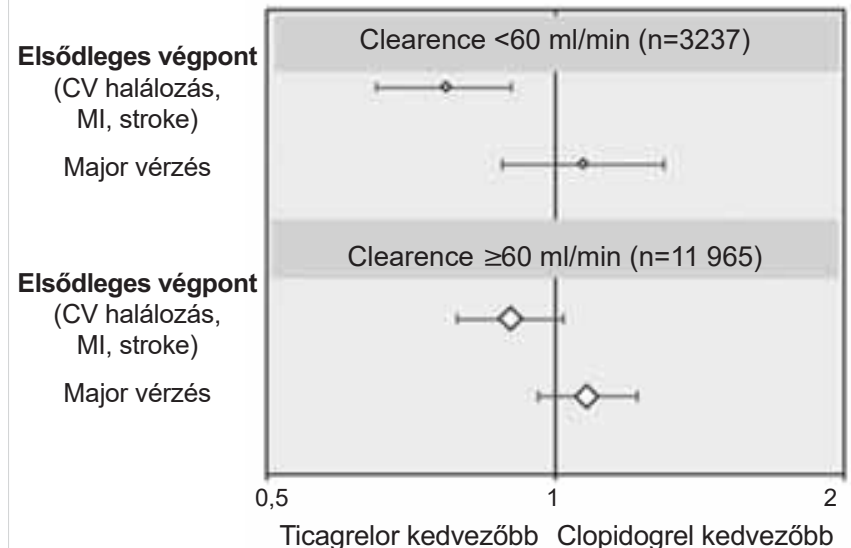

2. ÁBRA. A krónikus vesebetegség hatása az akut koronária szindróma miatt intervencionális kezelésre került betegek közt alkalmazott prasugrel, ticagrelor vagy clopidogrel klinikai eredményeire. Az adatok a TRITON-TIMI 38 vizsgálatban (A) és a PLATO-vizsgálatban (B) $60 \mathrm{ml} / \mathrm{min}$ alatti és feletti clearance-ű betegek bontásában mutatják be az ADP-gátló kezelés hatékonyságát. (Ml: miokardiális infarktus, CABG: koronária bypass műtét, CV: kardiovaszkuláris, na: nincs elérhető adat a TRITON TIMI38-vizsgálatból)

volt szignifikáns különbség a ticagrelor és a clopidogrel csoport között a major vérzések tekintetében.

A prasugrel és clopidogrel hatékonyságát és biztonságosságát a TRITON TIMI38-vizsgálatban elemezték (4). A veseelégtelenséggel bíró (11\%) betegcsoportban a clopidogrelhez képest nem igazolódott jelentősebb klinikai előny a nem vesebetegekhez képest: nem volt szignifikáns különbség a clopidogrelhez képest a kardiovaszkuláris halál, infarktus, stroke vonatkozásában (HR: 0,86; 95\%Cl: 0,67-1,1) (2. ábra) és az abszolút rizikócsökkenés sem tért el lényegesen egymástól a veseelégtelen és normál vesefunkciójú csoportokban. $2,4 \%$ vs. $2,1 \%$. Hasonló eredményeket észleltek a prasugrel és clopidogrel összevetésével nem invazív módon kezelt ACS-en átesett betegeknél a TRILOGY ACS-vizsgálatban is, a veseelégtelen csoport szignifikáns előnye nélkül $(22,23)$. Mindezek az eredmények ACS-en átesett veseelégtelen betegeknél a ticagrelor előnyét erősítik a prasugrellel szemben és validálják azt a finanszírozói hozzáállást, hogy az Eü70 30-as pont értelmében a $60 \mathrm{ml} / \mathrm{min}$ clearence-ü ACS-en átesett betegek támogatott módon ticagrelor kezelésben részesülhessenek.

Kiemelendő, hogy az EÜ pont kreatinin clearence-ben (Cockroft-Gault-formulával számított) adja meg a krónikus veseelégtelenség határát, míg a legtöbb labor MDRD vagy CKD-EPI alapján számított eGFR-eredményt tüntet fel leletein. A finanszírozási javaslat teljesítéséhez ezért fontos figyelembe venni az esetleges különbségeket, és a betegeknél akár újrakalkulálni a vesefunkció értékét az automatikus laborlelet mellett a kreatinin clearence-nek megfelelően.

\section{Clopidogrel nonreszponder betegek}

Konszenzusjavaslatok, foóbb megállapítások

1. ACS esetén clopidogrel kezelés mellett trombocitafunkciós teszttel azonosított magas trombocita-reaktivitással (HPR) bíró vagy genetikai teszt alapján funkcióvesztő mutációt hordozó (CYP2C19*2) nonreszponder betegeknél kontraindikáció hiányában feltétlenül prasugrel vagy ticagrelor terápiára történő átváltás javasolt, mert ezeknél a betegeknél a clopidogrel mellett jelentősen fokozott a tromboiszkémiás események kockázata.

2. ACS esetén clopidogrel kezelés mellett trombocitafunkciós teszt alapján normál trombocitareaktivitással (non-HPR) bíró vagy genetikai teszt alapján funkcióvesztő mutációt nem hordozó (CYP2C19*1*1) betegeknél egyéb magas rizikójú klinikai tényező nélkül (diabétesz, krónikus veseelégtelenség, stenttrombózis utáni állapot, technikai vagy anatómiai okokból szuboptimális eredményü PCl) a clopidogrel kezelés fenntartható, mert a várható tromboiszkémiás események kockázata alacsony.

3. ACS miatt prasugrellel vagy ticagrelorral kezelt betegeknél, ha a kezelés során vérzéses esemény, mellékhatás, vagy a kezelés folytatását akadályozó tényező lép fel (pl. gyógyszerkiváltást akadályozó anyagi nehézség), a clopidogrelre történő visszaváltás (deeszkaláció) elfogadható, ha a beteg funkcióvesztő mutációt nem hordoz (CYP2C19*2), vagy a clopidogrelre való átváltás után 7 nappal végzett aggregációs teszt alapján megfelelő aggregációgátlás igazolható.

4. Abban az esetben, ha a visszaváltás nem szociális indokú (pl. vérzés) és a clopidogrel mellett nonreszponzió igazolódik vagy a beteg ismerten funkcióvesztő mutációt hordoz (CYP2C19*2), prasugrel vagy ticagrelor alkalmazása megfontolandó az aszpirin terápia nélkül.

\section{Vizsgálati háttér}

A clopidogrel vérlemezkegátló hatása jelentős egyének közötti variabilitást mutat: ugyanazon fix dózisú gyógyszer hatására a betegek egy részénél (a mérőmódszer- 
től és a beteganyagtól függően 20-50\%) elégtelen, másoknál megfelelő, vagy akár túlzott vérlemezkegátló hatás is kialakulhat (3). Az elégtelen aggregációgátlással bíró betegeket korábban clopidogrel nonreszponderként említettük, jelenleg megfelelőbb elnevezés megkülönböztetésükre a kezelés ellenére megmaradó magas trombocitareaktivitás („High Platelet Reactivity" - HPR) (3). A HPR háttere összetett: egyrészt klinikai tényezők (elhízás, ACS, diabétesz, veseelégtelenség), másrészt genetikai okok magyarázzák a clopidogrel mellett észlelt elégtelen aggregációgátlást $(3,24)$. A genetikai faktorok közül a legnagyobb hatású a CYP2C19-gén funkcióvesztő mutációjának (CYP2C19*2) hordozása, amely a májban történő aktív metabolitképződést katalizáló enzim funkciójának jelentős csökkenését okozza, így csökkentve a clopidogrelből képződő aktív metabolitszintet (3).

Számos nagy esetszámú obszervációs vizsgálat igazolta, hogy a clopidogrel mellett HPR-rel bíró betegeknél jelentősen magasabb a miokardiális infarktus, stenttrombózis és kardiovaszkuláris halálozás előfordulása, mint a non-HPR egyéneknél (25). Mivel a prasugrelre vagy ticagrelorra történő átváltás hatékonyan megszünteti a HPR jelenlétét, ACS miatt PCI-n átesett betegeknél, amennyiben clopidogrel mellett HPR igazolódik, feltétlenül javasolt - kontraindikáció hiányában - a hatékonyabb APD-receptor-gátlókra történő áttérés. Bár korábbi trombocitafunkciós vizsgálatok (GRAVITAS, TRIGGER-PCI, ARCTIC) nem igazoltak előnyt a HPR-es betegeknél bevezetett erélyesebb aggregációgátló kezelésből, ezen vizsgálatok alacsony rizikójú, elektív beteganyagon történtek és nem a prasugrelre vagy ticagrelorra történő átváltást, hanem a clopidogrel dózisnövelését célozták (26-28). Fontos, hogy ACS esetén ezen betegek a nemzetközi szakmai útmutatókak megfelelően prasugrel vagy ticagrelor kezelést kapjanak úgy, hogy ha az átváltás az ACS korai fázisában (<1 hónap) történik, akkor ahhoz a prasugrel (60 $\mathrm{mg}$ ) vagy ticagrelor (180 mg) telítődózisát használjuk (2). Újabb klinikai vizsgálatok (TROPICAL ACS, RECLOSE-3 ACS) megerősítették, hogy a trombocitafunkciós teszt alapján HPR-rel bíró clopidogrelkezelt betegeket prasugrelre váltva az iszkémiás események kockázata csökkenhet, elérheti a non-HPR-betegek szintjét $(29,30)$. Ezek az eredmények cáfolják azt a korábbi feltételezést, hogy a HPR nem befolyásolható rizikómarker.

Fontos dilemma ugyanakkor, hogy a trombocitafunkció-mérés alapján clopidogrel mellett jó vérlemezkegátlással bíró, non-HPR-betegeknél ACS esetén folytatható-e a clopidogrel. Bár az ESC szakmai útmutatója szerint csak azon ACS-es betegeknél javasolt a clopidogrel, akiknél a prasugrel vagy ticagrelor nem elérhető, a magyar gyógyszertámogatási szabályozás alapján a clopidogrel mellett jó aggregációgátlással bíró, nem diabéteszes, veseelégtelen vagy stenttrombózis utáni betegeknél prasugrel vagy ticagrelor támogatott módon nem rendelhető, nem elérhető (2). Non-HPR-betegeknél a clopidogrel alkalmazása mellett érvelve fontos kiemelni a TROPICAL ACS klinikai vizsgálat eredményeit (29). A vizsgálatban 2610 beteget randomizáltak trombocitafunkciós mérés alapján irányított vérlemezkegátló kezelésre vagy rutinszerüen alkalmazott prasugrel terápiára (3. ábra). A vizsgálatban azon ACS-sel bíró betegeknél, akiknél a clopidogrel megfelelő aggregációgátlást biztosított nem volt különbség az iszkémiás események előfordulásában a prasugrelhez képest (29).

ACS miatt prasugrellel vagy ticagrelorral kezelt betegeknél előfordulhat olyan vérzéses esemény, mellékhatás (pl. dyspnoe) vagy a kezelés folytatását akadályozó körülmény (pl. az újabb ADP-receptorgátló magasabb

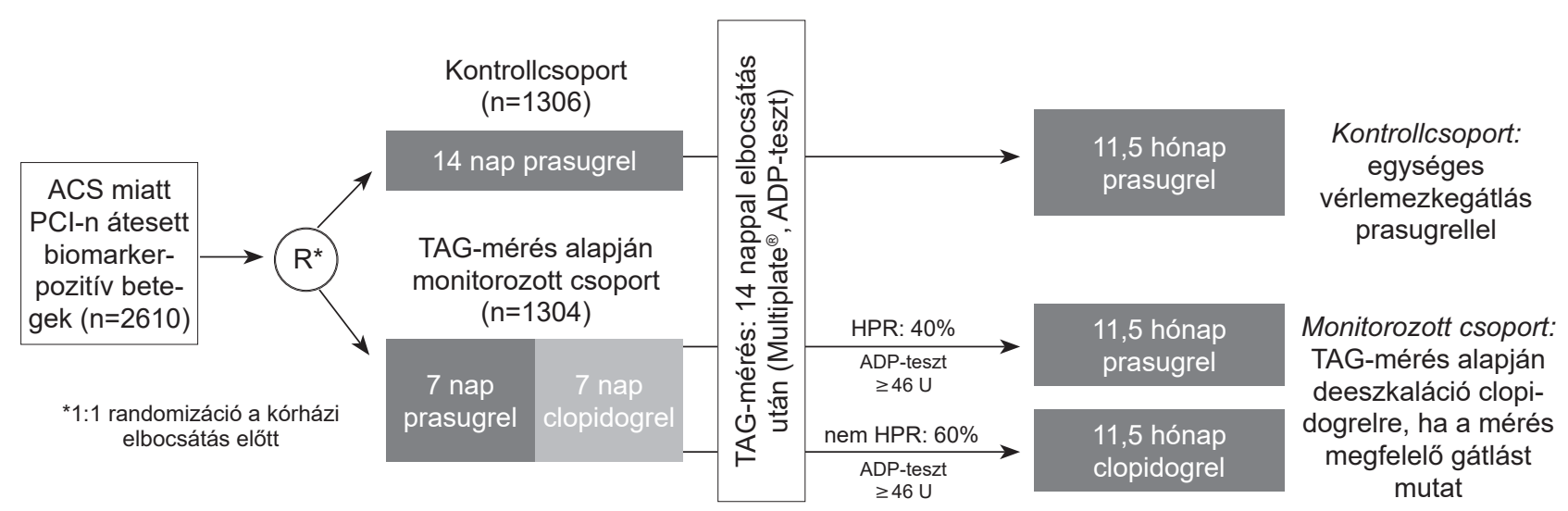

3. ÁBRA. A TROPICAL ACS klinikai vizsgálat elrendezése. A vizsgálatban 2610 biomarker-pozitív ACS miatt PCl-n átesett beteget randomizáltak a kórházi távozáskor egységes vérlemezkegátló kezelésre prasugrellel (kontrollcsoport) vagy TAG-mérés alapján megválasztott clopidogrel vagy prasugrel terápiára (TAG-mérés alapján monitorozott csoport). A TAG-vezérelt csoportban a betegek 60\%-át vissza lehetett váltani clopidogrelre 2 héttel a kórházi elbocsátást követően. Ez a deeszkalációs séma lehetőséget adhat mellékhatások vagy nem várt események esetén a biztonságos visszaváltásra akár 2 héttel a kórházi távozás után 


\section{Gyógyszeres szempontok optimalizálása}

- Clopidogrel mellett elszenvedett esemény esetén azonnali áttérés prasugrel vagy ticagrelor alkalmazására.

- Gyógyszerbevételi vagy felszívódási nehézség esetén, nagy thrombustehernél, prasugrel vagy ticagrelor mellett elszenvedett stenttrombózis kapcsán kiegészítő parenterális glikoprotein Ilb/Illa-gátló a PCl során.

- Gyógyszerszedési compliance tisztázása és erősítése.

- Bizonytalan gyógyszerhatás esetén TAG-hatékonyság mérése (gyógyszerhatást tükröző időpontban).

Angiográfia és rutin PCl

- Angiográfiásan megítélhető okok keresése és ellátása (alulméretezés, disszekció, súlyos instent resztenózis)

Képalkotó-vezérelt PCI (IVUS, OCT)

- Angiográfiásan nem egyértelmű procedurális ok esetén mindenképpen, de a lényegesen jobb szenzitivitás miatt rutinszerüen is javasolható intravaszkuláris képalkotó a hajlamosító tényezők vizsgálatára és az intervenciós megoldás megtervezésére (pl. nagy nyomású utótágítás jelentős malappozíció, alulexpanzió esetén, DEB-tágítás instent restenosis kapcsán, újabb stentimplantáció reziduális disszekció esetén).

4. ÁBRA. A stenttrombózis intervenciós ellátásának fő szempontjai (IVUS: intravaszkuláris ultrahang, OCT: optikai koherencia tomográfia)

anyagi terhe), amely miatt a betegnél clopidogrelre történő visszaváltás (deeszkaláció) indoka merül fel. A TROPICAL ACS-vizsgálatban a trombocitafunkció mérés eredménye alapján a betegek $60 \%$-át lehetséges volt clopidogrelre visszaváltani 14 nappal a $\mathrm{PCl}$ után, mert a visszaváltás után 7 nappal elvégzett trombocitafunkciós mérés megfelelő aggregációgátlást igazolt. Ez a stratégia klinikai eredményességet tekintve noninferiornak mutatkozott a kardiovaszkuláris halál, infarktus, stroke vagy BARC2-5 vérzés végpontja tekintetében az egy évig folyamatosan adagolt prasugrel kezeléssel (29). Az iszkémiás események aránya nem nőtt, a vérzéses kockázat tendencia szerint csökkent a deeszkalációs csoportban, amely alapján clopidogrelre visszaváltani biztonságosnak tủnik, ha az aggregációs mérés során megfelelő hatást észlelünk.

A 2019-es ESC kongresszuson bemutatott POPULAR-GENETICS randomizált vizsgálatban ugyanezen de-eszkalációs alapstratégiát vizsgálták genotípus alapján, 2488 STEMI miatt PCI-n átesett betegnél (31, 32). A genotípus-vezérelt csoportban a funkcióvesztő mutációt nem hordozó (CYP2C19 *1*1) egyének (a teljes csoport $67 \%$-a) clopidogrelt kaptak, csak a maradék 1/3-ad részesült ticagrelor kezelésben. A randomizált vizsgálat kontrollcsoportjának tagjai mind ticagrelor kezelésben részesültek. Az eredmények szerint a genotípus vezérelt deeszkaláció noninferior volt az iszkémiás végpont tekintetében, és kevesebb vérzést okozott, mint a ticagrelor. Mindezek alapján klinikai igény esetén mind a trombocitafunkció mérés, mind a genotipizálás alapján lehetséges a prasugrel/ticagrelor-ról történő visszaváltás.

Amennyiben a trombocitafunkció-mérés vagy a genotípizálás nem elérhető, vagy az eredmény alapján a betegnél a clopidogrel nem ideális (mert a trombocitafunkciós teszt alapján a beteg nonreszponder vagy a genotípusa szerint funkcióvesztő mutációt hordoz), a GLOBAL LEADERS klinikai vizsgálat eredménye alapján az aszpirin elhagyása fontolható meg 1 hónappal a $\mathrm{PCl}$ után (33). Bár a vizsgálat primer végpontja (össz- mortalitás vagy q-hullámmal járó miokardiális infarktus) alapján nem volt előnyösebb az aszpirint elhagyni 1 hónappal az ACS utáni PCl-t követően, a noninferior eredmények bizonyítékot szolgáltathatnak arra, hogy bár az aszpirin elhagyása ticagrelor mellöl 1 hónappal a $\mathrm{PCl}$ után rutinszerűen nem előnyösebb, mint a jelenlegi gyakorlat, de ez a stratégia hasonlóan biztonságos, mert nem növeli az iszkémiás események kockázatát.

\section{Stenttrombózison átesett betegek}

Konszenzus javaslatok, fooblo megállapítások 1. A stenttrombózis a koronáriaintervenció ritka, de magas mortalitási kockázatú, infarktussal kísért szövődménye. PCl után a kettős trombocitaaggregáció-gátló terápia alkalmazásának jelenleg is egyik fö célja ezen szövődmény hatékony megelőzése.

2. A stenttrombózis kialakulásában procedurális, keringési és farmakológiai okok egyaránt jelentős szerepet játszanak, ugyanakkor sokszor a pontos ok egyértelmü azonosítása nem lehetséges, az etiológiai tényezők gyakran keverednek és együttesen vezetnek a szövődményhez.

3. Clopidogrelkezelés mellett stenttrombózist elszenvedő betegeknél a revaszkularizáció képalkotó-vezérelt (OCT, IVUS) optimalizációja mellett a hatékonyabb aggregációgátlást biztositó új generációs ADP-receptor-gátlókra (prasugrel, ticagrelor) történő azonnali átváltás javasolt, függetlenül az esetlegesen feltárt procedurális tényezők vagy compliance problémák jelenlététől.

4. Prasugrel vagy ticagrelor mellett elszenvedett stenttrombózis esetén a revaszkularizáció képalkotó-vezérelt (OCT, IVUS) optimalizációja mellett a beteg-compliance szoros vizsgálata javasolt, és megfontolható a másik erélyes ADP-receptorgátló kezelésre történő áttérés.

5. Bár a vérlemezkegátló hatékonyság szempontjából lényeges különbség a prasugrel és ticagrelor között nincs, jelenleg elérhető klinikai vizsgálati ered- 
mények összessége alapján a stenttrombózis megelőzésében a prasugrel hatékonyabbnak tünik mint a ticagrelor, emiatt stenttrombózis esetén kontraindikáció hiányában ez az elsődlegesen javasolt ADP-receptorgátló.

\section{Vizsgálati háttér}

A stenttrombózis a $\mathrm{PCl}$ utáni trombotikus szövődmények ritka, de magas mortalitású típusa. A korábban beültetett stent hirtelen elzáródásával járó trombotikus okklúzió általában hirtelen szívhalál vagy ST-elevációs miokardiális infarktus képében jelentkezik. Kimenetele egyes adatok alapján rosszabb a de novo kialakult infarktusénál; mortalitása az irodalmi közlések alapján széles határokon belül mozog, 5-45\%-os (34-36). Az 5 éven belüli rekurrencia aránya magas, elérheti akár az 5-15\%-ot is. Fontos kiemelni, hogy a stenttrombózis incidenciája az elmúlt évtizedben jelentősen csökkent a gyógyszeres terápia, a stenttechnológia és a képalkotó-vezérelt intervenció lehetőségeinek fejlődésével; ennek ellenére megelőzése jelenleg is kiemelt cél a $\mathrm{PCl}$ biztonságosságának biztosítására.

Számos, egymástól független, de gyakran egyszerre jelen lévő tényező játszik közre az egyén stenttrombózis rizikójának kialakításában. Ezek közül meghatározó a vérlemezke-aggregáció-gátló kezelés hatékonysága mellett a stentimplantáció technikai kivitelezése (elégtelen stentexpanzió, malappozíció, stenttörés, széli disszekció), a koronáriaszklerózis kiterjedtsége (szükséges implantált stentek száma) és jellege (meszes léziók, jelentős thrombusteher, rossz kiáramlás, bifurkációs szükület), valamint az általános keringési viszonyok hatása (sokk, jelentősen csökkent szisztolés balkamra-funkció, trombocitózis) (34-36). Ugyanakkor az esetek jelentős részében a trombotikus elzáródáshoz vezető ok vagy okok egyértelmüen nem azonosíthatók, ezért a kezelési stratégiának mind a technikai tökéletesítést (képalkotó-vezérelt revaszkularizáció), mind az aggregációgátlás optimalizálását együttesen kell megcéloznia (4. ábra).

A stenttrombózis gyanújával vizsgált beteget azonnal $\mathrm{PCl}$ központba szükséges utalni, ahol késlekedés nélkül el kell végezni az angiográfiát, amely a diagnózist szolgáltatja. Az angiográfia bizonyos esetekben már magyarázatot adhat a háttérben lévő okokról és mechanizmusokról, de a lényegesen jobb szenzitivitás miatt az intravaszkuláris képalkotó vizsgálatok alkalmazása javasolt (IVUS/OCT) a procedurális tényezők tisztázására, elkülönítésére és a szükséges további intervencionális kezelés megtervezésére. Ugyanakkor ezzel párhuzamosan haladéktalanul szükséges megkezdeni a gyógyszeres kezelési optimalizációját is (4. ábra).

A stenttrombózis kivédésében a clopidogrel kezeléshez képest mindkét újgenerációs ADP-receptor-antagonista (prasugrel, ticagrelor) hatékonynak bizonyult. A TRITON TIMI38-vizsgálatban (4) a prasugrel a clopi-
A

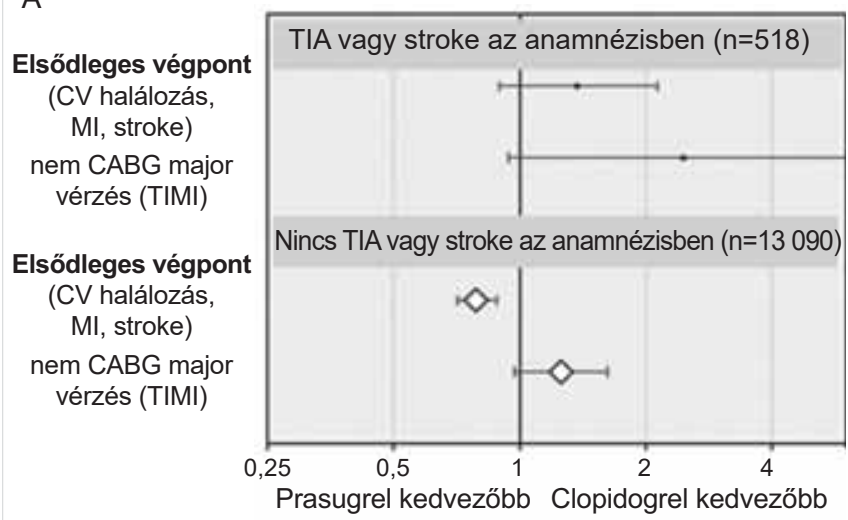

B

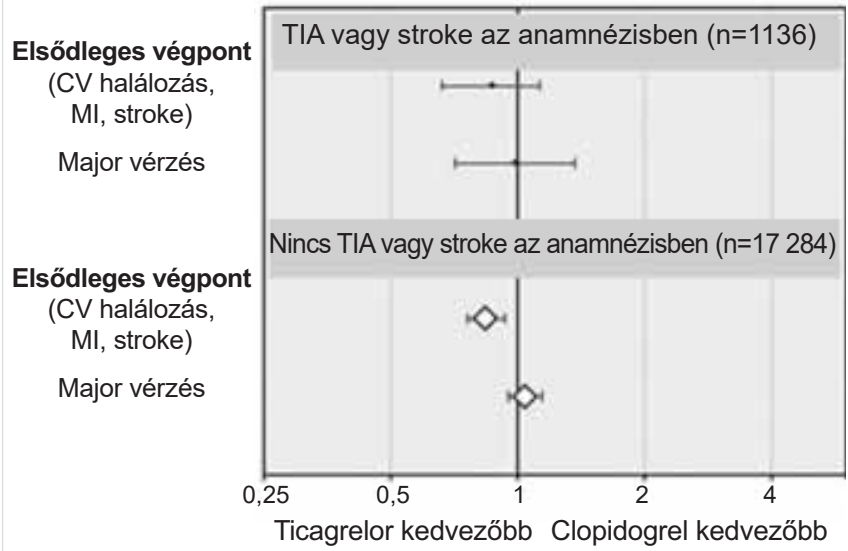

5. ÁBRA. Korábbi iszkémiás agyi esemény hatása az akut koronária szindróma miatt kezelt betegek iszkémiás és vérzéses eseményeinek

Az A-ábrarész a TRITON TIMI38-vizsgálat eredményeit mutatja a prasugrel és clopidogrel összehasonlításában, míg a B-rész a ticagrelor és clopidogrel összevetést a PLATO-vizsgálat alapján (MI: miokardiális infarktus, TIMl: trombolízis miokardiális infarktusban [definíció], CABG: koronária bypass mútét, CV: kardiovaszkuláris)

dogrelhez képest 52\%-kal csökkentette a stenttrombózis relatív rizikóját (1,1\% vs. 2,4\%, HR: 0,48; $95 \% \mathrm{Cl}$ : 0,36-0,64 p<0,001), míg a PLATO-vizsgálatban (5) a ticagrelor mellett szintén jelentős, 25\%-os rizikócsökkenés volt kimutatható $(2,2 \%$ vs. $2,9 \% \mathrm{HR}$ : 0,75; 95\% Cl: 0,59-0,95 p=0,02). Emiatt, abban az esetben, ha clopidogrel mellett következik be a stenttrombózis, javasolt prasugrel vagy ticagrelor azonnali elindítása (prasugrel: 60 mg telítődózis majd 10 mg fenntartó, ticagrelor: 180 mg telítődózis és $2 \times 90$ mg fenntartó) attól függetlenül, hogy a stenttrombózis hátterében technikai okot sikerül-e igazolni vagy feltételezni.

Bár a prasugrel és a ticagrelor aggregációgátló hatékonyságában jelentős különbség trombocitafunkciós vizsgálatok szerint nincs, a stenttrombózis csökkentésében indirekt összehasonlítás alapján a prasugrel jelentősebb csökkenést eredményezett a clopidogrelhez képest, mint a ticagrelor: TRITON-vizsgálatban a prasugrel 52\%-kal (4), a PLATO-vizsgálatban (5) a ticag- 
relor 25\%-kal csökkentette a stenttrombózis rizikóját. Az első nagy esetszámú, direkt összevetést biztosító randomizált vizsgálat is a prasugrel előnyét mutatta ebben a tekintetben, hiszen az ISAR-REACT-5-vizsgálatban a 4018 ACS miatt invazív stratégiával kezelt beteg között a prasugrel kezelésre randomizált csoportban alacsonyabb volt a biztos stenttrombózis $(1,1 \%$ vs. $0,6 \%)$ és a miokardiális infarktus előfordulása (37). Emiatt, bár a kis abszolút rizikókülönbség klinikai validitása továbbra is kérdéses, stenttrombózis esetén a jelenleg rendelkezésre álló eredmények alapján elsődlegesen preferáltható ADP-receptor-gátló a prasugrel.

Prasugrel vagy ticagrelorkezelt betegekben a stenttrombózis előfordulása lényegesen ritkább, de a folyamat hátterében álló összetett rizikótényezők ismeretében nem meglepő, hogy stenttrombózis megjelenésével ezen erélyes ADP-receptor-gátlók mellett is számolnunk kell. Ezekben az esetekben a $\mathrm{PCl}$ során intravénás vagy intrakoronáriás glikoprotein llb/ Illa-blokkoló alkalmazása javasolt, a gyógyszerszedési compliance felderítésével. Ha compliance probléma nem valószínűsíthető, másik erélyes ADP-receptor-gátlóra történő áttérés megfontolható, bár erre vonatkozó klinikai bizonyíték nem áll rendelkezésre. A stenttrombózis után, a gyógyszerhatást tükröző időpontban (glikoprotein IIb/IIla-blokkoló leállítása után 12-24 órával) a beállított gyógyszeres stratégia hatékonyságának ellenőrzésére, trombocitaaggregáció mérés megfontolható. Bár a clopidogrelhez képest a prasugrel és ticagrelor fokozza az ADP-receptor-gátlást és csökkenti a magas trombocita-reaktivitást (HPR), az irodalmi adatok alapján izolált nonreszponder esetek előfordulhatnak prasugrel és ticagrelor mellett is.

\section{Stroke-on átesett betegek}

Konszenzusjavaslatok, fóblo megállapítások

1. Azon akut koronária szindróma miatt PCI-n átesett betegek esetében, akik anamnézisében korábbi agyi iszkémiás esemény, stroke vagy tranziens iszkémiás attak (TIA) szerepel a prasugrel alkalmazása kontraindikált, mert a clopidogrelhez képest mind az iszkémiás, mind a vérzéses események rizikója fokozódhat. A ticagrelor esetén a korábbi stroke vagy TIA nem jelent kontraindikációt, mert a hatékonyság és biztonságosság nem mutat eltérést az agyi iszkémiás eseménytöl mentes betegekhez képest.

2. Korábban intracranialis vérzésen átesett beteg esetében akut koronária szindróma esetén is javasolt a kettős aggregációgátlás, rutinszerüen aszpirin és clopidogrel kombinációjával. Magas vérzéses kockázat (PRECISE-DAPT score $\geq 25$ ) esetén a clopidogrel alkalmazása 6 hónappal a $P C l$ után felfüggeszthető.

\section{Vizsgálati háttér}

Bár az akut miokardiális infarktus és az agyi iszkémiás események patomechanizmusában több közös folyamat azonosítható (pl. aterotrombózis folyamatának ateroszklerotikus alapja), megelőzésük az aggregációgátló kezelés hatékonysága szempontjából lényeges különbségeket mutat. Akut miokardiális infarktust követően az ADP-receptor-gátlás erélyességének fokozása jelentősen csökkenti az ismételt miokardiális infarktus kialakulásának veszélyét, ezért ebben a tekintetben a prasugrel és ticagrelor előnye egyértelmü a clopidogrelhez képest. Ugyanakkor az ADP-receptor-gátlók között lényeges különbség észlelhető a stroke megelőzés és a stroke-on átesett betegek iszkémiás eseményeinek kivédésében (38).

A TRITON TIMI-38-vizsgálatban (4) 13608 ACS miatt $\mathrm{PCl}-\mathrm{n}$ átesett betegnél a prasugrel és clopidogrel öszszehasonlítása során a kardiovaszkuláris halálozás, infarktus és stroke összetett végpontja jelentősen csökkent a prasugrel csoportban, $(p<0,001)$, ebböl azonban a nem fatális stroke gyakorisága nem csökkent a prasugrel kezeléssel (HR: 1,02; 95\% Cl: 0,71-1,45 p=0,93). Hasonló eredményt hozott a TRILOGY ACS-vizsgálat is, melyben ACS-en átesett, de nem intervencióval kezelt betegeknél tesztelték a prasugrel hatékonyságát a clopidogrelhez képest (22). A teljes kohortban a prasugrel nem csökkentette a stroke rizikóját (HR: 0,89 ; 95\% Cl: 0,63-1,26 p=0,52).

A TRITON-vizsgálatba bevont betegek közül 518 fő esetén korábbi stroke vagy tranziens iszkémiás esemény (TIA) került leírásra (4). Ezen kis alcsoportban a prasugrel mind az elsődleges iszkémiás, mind a vérzéses végpontban magasabb kockázatot mutatott a clopidogrelhez képest, az összesített nettó klinikai haszon szignifikánsan rosszabb volt prasugrel mellett (5. ábra). Ezért a beteg anamnézisében szereplő stroke vagy TIA abszolút kontraindikációt képez a prasugrel kezelés szempontjából.

A ticagrelor klinikai hatékonyságát a clopidogrellel szemben ACS-en átesett betegeknél a PLATO randomizált, multicentrikus klinikai vizsgálatban elemezték (5). A 18624 randomizált beteg között a stroke előfordulása hasonló volt a ticagrelor és clopidogrel csoportban (1,5\% vs. 1,3\% HR: 1,17; 95\% Cl: 0,91-1,52 p=0,22) (2). Azon betegek között, akiknél az anamnézisben stroke/ TIA szerepel, a vizsgálat során a teljes beteganyaggal konzisztens eredményeket észleltek, ezért korábbi iszkémiás cerebrovaszkuláris esemény a ticagrelor alkalmazását nem befolyásolja (5. ábra).

\section{Következtetések}

A hatékony $\mathrm{P}_{2} \mathrm{Y}_{12}$-gátló gyógyszerek jelentős előrelépést hoztak az akut koronária szindróma miatt ellátott betegek kezelésében, jelentősen csökkentve a kardiovaszkuláris halálozás, miokardiális infarktus és stent- 

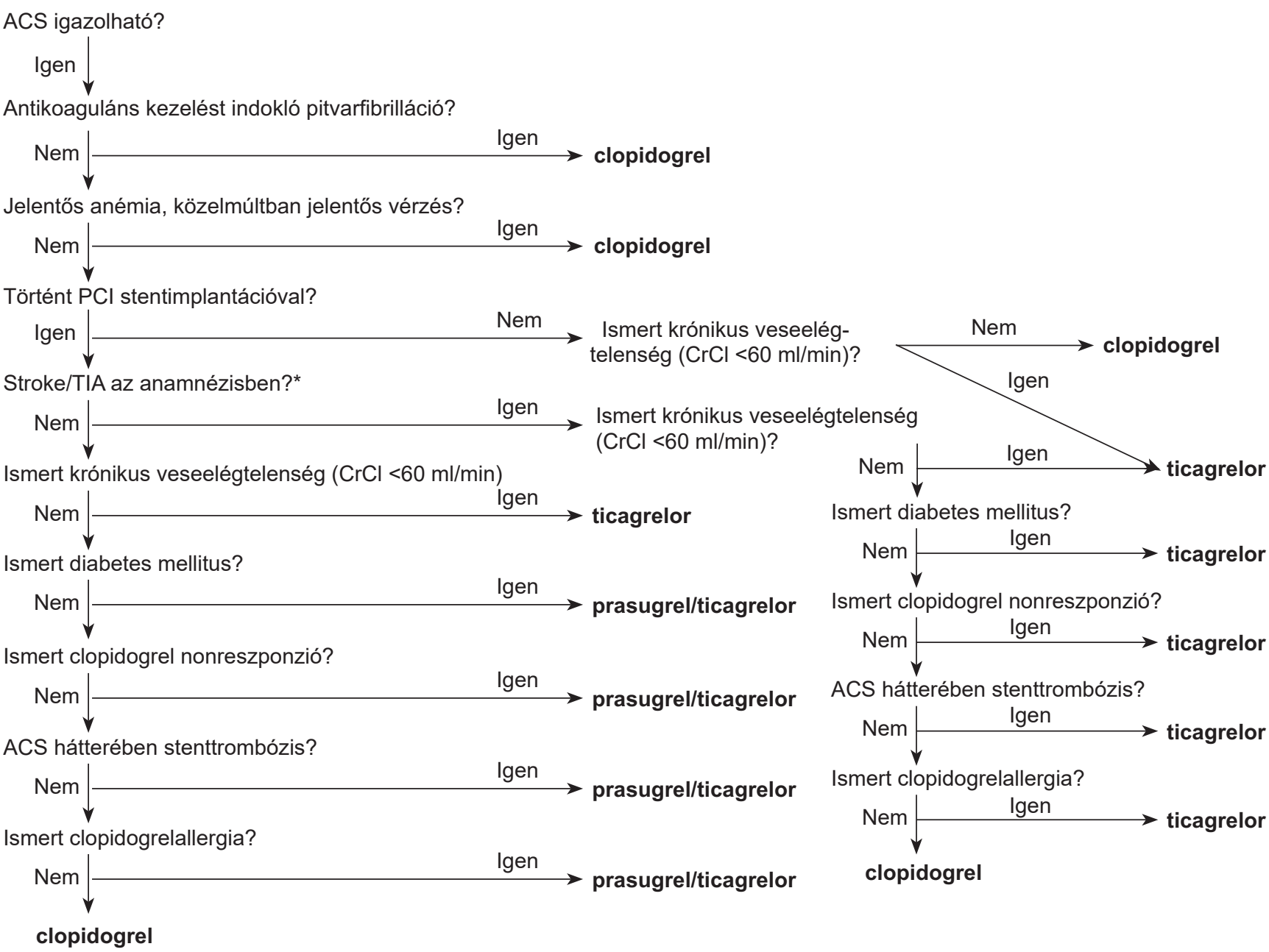

Ismert diabetes mellitus?

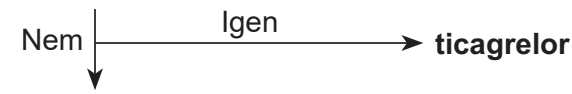

Ismert clopidogrel nonreszponzió?

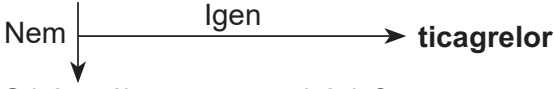

ACS hátterében stenttrombózis?

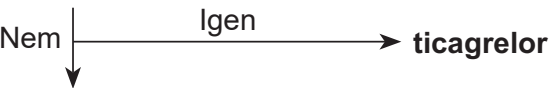

Ismert clopidogrelallergia?

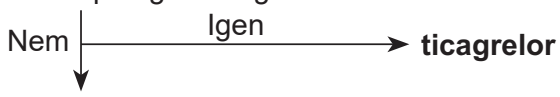

clopidogrel

6. ÁBRA. Javasolt algoritmus az optimális ADP-receptor-gátló kezelés kiválasztásához a magyar finanszírozási protokoll figyelembevételével

trombózis előfordulását. Természetesen ez az előny a vérzéses kockázat fokozódásával járt együtt, de mind a prasugrel, mind a ticagrelor esetén olyan jelentős nettó klinikai előny mutatkozik, hogy a napi rutinban a szakmai útmutatók ezeket a terápiákat preferált választássá tették clopidogrellel szemben ACS esetén. Bár a magyar finanszírozási protokoll szükebbre szabja a támogatás révén a kezelhető beteganyagot, a diabéteszes, krónikus veseelégtelenséggel bíró, clopidogrel nonreszponder vagy stenttrombózison átesett betegek kiemelt előnyt szerezhetnek a prasugrel vagy ticagrelor terápia alkalmazásából. Stroke-on vagy TIA-án átesett betegnél a prasugrel kontraindikált, de a ticagrelorral elérhető eredmények megfelelő mérlegeléssel itt is jó terápiás lehetőséget nyújtanak. A napi gyakorlatban sokszor komplexnek tűnő, sok szempontot integráló terápiás választáshoz az 6 . ábra próbál meg gyakorlati segítséget nyújtani, ahol az optimális P2Y ${ }_{12}$-gátló gyógyszer kiválasztásának folyamata a beteg társbetegségeinek függvényében jól modellezhető.

Reményeink mindezen szakmai információk, konszenzus javaslatok és gyógyszerválasztási modell elősegítik majd a hazai viszonylatban jelenleg kifejezetten alacsony arányú modern $\mathrm{P}_{2} \mathrm{Y}_{12}$-gátló alkalmazását a nemzetközi irányelvek elvárásainak megfelelően.

*Kiemelendő, hogy a 2018.10.15-én Magyar Közlönyben megjelent finanszírozási rendelet Eü70 24-es pontjának megfelelő módosított rendelkezésében az anamnézisben szereplö TIA/stroke kontraindikációként van megjelölve egyaránt a prasugrel és ticagrelor esetén, nem differenciálva az egyértelműen kontraindikált prasugrel és az alkalmazható ticagrelor között. A szerzők véleménye, hogy ez a szakmailag hibás megfogalmazás a közeljövőben korrekcióra kerülhet, hiszen már jelenleg is konfliktusban áll a 2018.10.15-töl hatályos 35/2018. (X. 12.) EMMI-rendelettel, amelyben a ticagrelor esetén az anamnézisben szereplő korábbi stroke/TIA nem szerepel kontraindikációként az ACS-es betegek megjelölt típusainál 


\section{Irodalom}

1. Koupenova, M., et al. Thrombosis and platelets: an update. Eur Heart J, 2017. 38(11): p. 785-791. DOI: 10.1093/eurheartj/ehw550

2. Valgimigli, M., et al. 2017 ESC focused update on dual antiplatelet therapy in coronary artery disease developed in collaboration with EACTS: The Task Force for dual antiplatelet therapy in coronary artery disease of the European Society of Cardiology (ESC) and of the European Association for Cardio-Thoracic Surgery (EACTS). Eur Heart J, 2018. 39(3): p. 213-260. DOI: 10.1093/eurheartj/ehx419

3. Sibbing, D, et al. Updated Expert Consensus Statement on Platelet Function and Genetic Testing for Guiding P2Y ${ }_{12}$ Receptor Inhibitor Treatment in Percutaneous Coronary Intervention. JACC Cardiovasc Interv, 2019. 12(16): p. 1521-1537. DOI: 10.1016/j.jcin.2019.03.034

4. Wiviott, SD, et al. Prasugrel versus clopidogrel in patients with acute coronary syndromes. N Engl J Med, 2007. 357(20): p. 2001-15. DOI: 10.1056/NEJMoa0706482

5. Wallentin, L, et al. Ticagrelor versus clopidogrel in patients with acute coronary syndromes. N Engl J Med, 2009. 361(11): p. 1045-57. DOI: 10.1056/NEJMoa0904327

6. Neumann, FJ, et al. 2018 ESC/EACTS Guidelines on myocardial revascularization. Eur Heart J, 2019. 40(2): p. 87-165. DOI: 10.1093/eurheartj/ehy394

7. Janosi, A. Nemzeti Szívinfarktus Regiszter: akut ellátás, szekunder prevenció, késői események. in Budapesti Kardiológiai Napok. 2016. Budapest. 8. Janosi, A, et al. [Patient care of patients with myocardial infarction in Hungary. Analysis of National Myocardial Infarction Registry data collecting in 2015]. Orv Hetil, 2017. 158(3): p. 90-93. DOI: 10.1556/650.2017.30670

9. Janosi, A, et al. [Short and long term prognosis of patients with myocardial infarction. Hungarian Myocardial Infarction Registry]. Orv Hetil, 2013. 154(33): p. 1297-302. DOI: 10.1556/OH.2013.29679

10. Hajar, R, Diabetes as "Coronary Artery Disease Risk Equivalent": A Historical Perspective. Heart Views, 2017. 18(1): p. 34-37. DOI: 10.4103 HEARTVIEWS.HEARTVIEWS_37_17

11. Steg, PG, et al. Ticagrelor in Patients with Stable Coronary Disease and Diabetes. N Engl J Med, 2019. DOI: 10.1056/NEJMoa1908077

12. Bhatt, DL. et al. Ticagrelor in patients with diabetes and stable coronary artery disease with a history of previous percutaneous coronary intervention (THEMIS-PCI): a phase 3, placebo-controlled, randomised trial. Lancet, 2019. e-pub. DOI: 10.1016/S0140-6736(19)31887-2

13. Bonaca, MP, et al. Long-term use of ticagrelor in patients with prior myocardial infarction. N Engl J Med, 2015. 372(19): p. 1791-800. DOI: 10.1056/NEJMoa1500857

14. Santilli, F, et al. Platelets and diabetes mellitus. Prostaglandins Other Lipid Mediat, 2015. 120: p. 28-39. DOI: 10.1016/j.prostaglandins.2015.05.002

15. Angiolillo, DJ, et al. Platelet function profiles in patients with type 2 diabetes and coronary artery disease on combined aspirin and clopidogrel treatment. Diabetes, 2005. 54(8): p. 2430-5. DOI: 10.2337/diabetes.54.8.2430

16. Angiolillo, DJ, et al. Impaired responsiveness to the platelet P2Y12 receptor antagonist clopidogrel in patients with type 2 diabetes and coronary artery disease. J Am Coll Cardiol, 2014. 64(10): p. 1005-14. DOI: 10.1016/j.jacc.2014.06.1170

17. James, S, et al. Ticagrelor vs. clopidogrel in patients with acute coronary syndromes and diabetes: a substudy from the PLATelet inhibition and patient Outcomes (PLATO) trial. Eur Heart J, 2010. 31(24): p. 300616. DOI: 10.1093/eurheartj/ehq325

18. Shroff, GR. and T.I. Chang, Risk Stratification and Treatment of Coronary Disease in Chronic Kidney Disease and End-Stage Kidney Disease. Semin Nephrol, 2018. 38(6): p. 582-599. DOI: 10.1016/j.semnephrol.2018.08.004

19. Piepoli, MF, et al. 2016 European Guidelines on cardiovascular disease prevention in clinical practice: The Sixth Joint Task Force of the European Society of Cardiology and Other Societies on Cardiovascular Disease Prevention in Clinical Practice (constituted by representatives of 10 societies and by invited experts)Developed with the special contribution of the European Association for Cardiovascular Prevention \& Rehabilitation (EACPR). Eur Heart J, 2016. 37(29): p. 2315-2381. DOI: 10.1093/eurheartj/ehw106

20. Patti, G, et al. Impact of Chronic Renal Failure on Ischemic and Bleeding Events at 1 Year in Patients With Acute Coronary Syndrome (from the Multicenter START ANTIPLATELET Registry). Am J Cardiol, 2018.
122(6): p. 936-943. DOI: 10.1016/j.amjcard.2018.05.049

21. James, S, et al. Ticagrelor versus clopidogrel in acute coronary syndromes in relation to renal function: results from the Platelet Inhibition and Patient Outcomes (PLATO) trial. Circulation, 2010. 122(11): p. 1056-67. DOI: 10.1161/CIRCULATIONAHA.109.933796

22. Roe, MT, et al. Prasugrel versus clopidogrel for acute coronary syndromes without revascularization. N Engl J Med, 2012. 367(14): p. 1297309. DOI: $10.1056 /$ NEJMoa1205512

23. Melloni, C, et al. Impact of chronic kidney disease on long-term ischemic and bleeding outcomes in medically managed patients with acute coronary syndromes: Insights from the TRILOGY ACS Trial. Eur Heart J Acute Cardiovasc Care, 2016. 5(6): p. 443-454. DOI: 10.1177/2048872615598631

24. Komocsi, AR, L.; Kiss, R.G.; Becker, D.; Keltai, M.; Aradi, D., Konszenzus ajánlás a trombocitaaggregáció-gátlás méréséről koronária stent-implantáción átesett betegek esetén. Cardiologica Hungarica, 2011. 41: p. O2-O19.

25. Aradi, D, et al. Prognostic significance of high on-clopidogrel platelet reactivity after percutaneous coronary intervention: systematic review and meta-analysis. Am Heart J, 2010. 160(3): p. 543-51. DOI: 10.1016/j. ahj.2010.06.004

26. Price, MJ, et al. Standard- vs high-dose clopidogrel based on platelet function testing after percutaneous coronary intervention: the GRAVITAS randomized trial. JAMA, 2011. 305(11): p. 1097-105. DOI: 10.1001 jama.2011.290

27. Collet, JP, et al. Bedside monitoring to adjust antiplatelet therapy for coronary stenting. N Engl J Med, 2012. 367(22): p. 2100-9. DOI: 10.1056/NEJMoa1209979

28. Trenk, D, et al. A randomized trial of prasugrel versus clopidogrel in patients with high platelet reactivity on clopidogrel after elective percutaneous coronary intervention with implantation of drug-eluting stents: results of the TRIGGER-PCI (Testing Platelet Reactivity In Patients Undergoing Elective Stent Placement on Clopidogrel to Guide Alternative Therapy With Prasugrel) study. J Am Coll Cardiol, 2012. 59(24): p. 215964. DOI: 10.1016/j.jacc.2012.02.026

29. Sibbing, D, et al. Guided de-escalation of antiplatelet treatment in patients with acute coronary syndrome undergoing percutaneous coronary intervention (TROPICAL-ACS): a randomised, open-label, multicentre trial. Lancet, 2017. 390(10104): p. 1747-1757. DOI: 10.1016/S01406736(17)32155-4

30. Valenti, $\mathrm{R}$, et al. Prasugrel in Clopidogrel Nonresponders Undergoing Percutaneous Coronary Intervention: The RECLOSE-3 Study (REsponsiveness to CLOpidogrel and StEnt Thrombosis). JACC Cardiovasc Interv, 2015. 8(12): p. 1563-70. DOI: 10.1016/j.jcin.2015.07.010

31. Bergmeijer, TO, et al. CYP2C19 genotype-guided antiplatelet therapy in ST-segment elevation myocardial infarction patients-Rationale and design of the Patient Outcome after primary PCI (POPular) Genetics study. Am Heart J, 2014. 168(1): p. 16-22 e1. DOI: 10.1016/j.ahj.2014.03.006 32. Claassens, DMF, et al. A Genotype-Guided Strategy for Oral P2Y12 Inhibitors in Primary PCI. N Engl J Med, 2019. DOI: 10.1056/NEJMoa1907096

33. Vranckx, $P$, et al. Ticagrelor plus aspirin for 1 month, followed by ticagrelor monotherapy for 23 months vs aspirin plus clopidogrel or ticagrelor for 12 months, followed by aspirin monotherapy for 12 months after implantation of a drug-eluting stent: a multicentre, open-label, randomised superiority trial. Lancet, 2018. 392(10151): p. 940-949. DOI: 10.1016/S0140-6736(18)31858-0

34. Claessen, BE, et al. Stent thrombosis: a clinical perspective. JACC Cardiovasc Interv, 2014. 7(10): p. 1081-92. DOI: 10.1016/j. jcin.2014.05.016

35. Torrado, J, et al. Restenosis, Stent Thrombosis, and Bleeding Complications: Navigating Between Scylla and Charybdis. J Am Coll Cardiol, 2018. 71(15): p. 1676-1695. DOI: 10.1016/j.jacc.2018.02.023

36. Mauri, L, et al. Stent thrombosis in randomized clinical trials of drug-eluting stents. N Engl J Med, 2007. 356(10): p. 1020-9. DOI: 10.1056/NEJMoa067731 37. Schupke, S, et al. Ticagrelor or Prasugrel in Patients with Acute Coronary Syndromes. N Engl J Med, 2019. DOI: 10.1056/NEJMoa1908973

38. Aradi, $\mathrm{D}$ et al. Impact of clopidogrel and potent $\mathrm{P} 2 \mathrm{Y}_{12}$-inhibitors on mortality and stroke in patients with acute coronary syndrome or undergoing percutaneous coronary intervention: a systematic review and meta-analysis. Thromb Haemost, 2013. 109(1): p. 93-101. DOI: 10.1160/ TH12-06-0377 